\title{
The Effect of Decentralization and Free Trade Agreements on Regional Disparity in a Developing Economy: The Case of Indonesia, 1993-2005
}

\author{
Adiwan Aritenang \\ a.aritenang@gmail.com \\ Department of Urban and Regional Planning \\ Bandung Institute of Technology, Indonesia \\ Jung Won Sonn* \\ j.sonn@ucl.ac.uk \\ Bartlett School of Planning \\ University College London, UK
}

\begin{abstract}
*Corresponding author
Acknowledgement: During this research, Sonn was financially supported by Ministry of Education of the Republic of Korea and the National Research Foundation of Korea (Grant code NRF2015S1A3A2047036)
\end{abstract}

\begin{abstract}
Since 1993, Indonesia has experienced both upward and downward restructuring of state power through the ASEAN Free Trade Agreement (AFTA) and fiscal decentralization, respectively. In this study, we investigate the impact of state restructuring on regional disparity. Indonesia is an interesting case because it is one of the few economies in which the upward and downward restructuring of state power occurred almost simultaneously. Based on a panel data analysis of micro-level firm data for the period 19932005, we find evidence of neoclassical convergence. Furthermore, decentralization was found to slow this convergence, while the AFTA had no statistically significant impact during the study period.
\end{abstract}

\section{Introduction}

During the post-war era, the central government was the main actor in policies focusing on regional balance in many countries (McFarquhar, 1996; Renaud, 1981; Lee and Kang, 2012). Central governments attempted to reduce regional disparity by offering intergovernmental transfer funds and by investing in the infrastructure of less developed regions directly. Many governments also offered tax incentives to firms wanting to locate branches in less developed regions. However, since the $1980 \mathrm{~s}$, the perception is that active intervention by a central government became increasingly difficult owing to its partial loss of power upward (i.e., multilateral free trade agreements) and downward (i.e., fiscal decentralization). This study examines whether these perceived difficulties actually have an impact on regional disparity.

Existing discussions on related issues predict that state restructuring increases regional disparity. The benefit of trade liberalization is likely to be assumed by competitive industries in which export opportunities exist. Less competitive industries will lose their domestic market owing to the importation of foreign products. Thus, since industries tend to 
concentrate rather than disperse across regions, those regions that host competitive industries will benefit, while those that host less competitive industries will lose out (Sonn and Lee, 2012). Furthermore, this impact is not static. Rather, as a result of economies of scale, disparity grows over time (Krugman, 1980; Sjöberg and Sjöholm, 2004).

Financial devolution also potentially enhances regional disparity. Firstly, smaller regions do not have the scale necessary for efficient production and delivery of public services (Rodríguez-Pose and Ezcurra, 2011). Secondly, larger districts are likely to generate higher revenue because they have a bigger tax base owing to their larger economy. Consequently, in the long run, the development gap between richer and poorer districts will increase. Thirdly, decentralization is likely to intensify competition among local governments over incoming investment and tax revenue, which leads to unnecessary and inefficient development. In this sense, local economic growth may lead to a zero-sum competition, which is more detrimental to underdeveloped regions. Finally, in competing for incoming investment, developed regions that have more to offer are more likely to win, thereby exacerbating the disparity.

In this study, we examine these theoretical predictions in the context of Indonesia. Indonesia is an interesting case, because the state power has been restructured upward, through the ASEAN Free Trade Agreement (AFTA), and downward, through fiscal decentralization. For our empirical analysis, we use micro-level firm data for the period 1993-2005, along with other datasets. The paper focuses to determine Indonesia's readiness for ASEAN toward ASEAN Economic Community in 2015. As such, the AFTA as a building block of trade liberalization in ASEAN region

\section{State restructuring and regional disparity}

Since 1993, the effects of state restructuring have attracted academic interest in the fields of regional science, political science, geography, planning, and other related fields. Theory predicts that regions in which both upward and downward state restructuring occurs diverge in terms of their economic disparity. This prediction appears to be supported by evidence from prior studies.

\subsection{The effect of upward restructuring}

Empirical studies focusing on developing economies almost all show a positive correlation between trade openness and regional disparity. ${ }^{1}$ For example, Egger et al. (2005), who focused on Central and Eastern Europe using a generalized method of moments (GMM) estimator, found increasing disparity in the wage level of regions in countries with increasing trade openness. In their analysis of Mexico, many researchers agree that trade openness is associated with the concentration of industries (e.g., Chiquiar, 2005; Faber, 2007; Hanson, 1997, 1998; Rodríguez-Pose and Sanchez-Reaza, 2005). Similarly, Pernia and Quising (2003) reported that, in the Philippines, export activities were highly concentrated in Manila, a tendency that resulted in increasing disparity between Manila and the rest of the country. In Brazil, Daumal and Ozyurt's (2010) analysis found that trade openness contributed to an increase in the income level of rich industrial regions only, thereby increasing the gap between the industrial and non-industrial regions. Fu (2004) showed that, in China, an increase in exports mainly benefits growth in the developed provinces of the East Coast, thus

\footnotetext{
${ }^{1}$ On the other hand, empirical cross-country analyses have found little evidence of increasing disparity. See Ades and Glaeser (1995), Brulhart and Sbergami (2008), Nitsch (2006), and Ramcharan (2009), among others.
} 
widening regional disparity. Also in China, it has been found that foreign direct investment contributes to an increase in regional disparity (He, Wei, and Xie, 2009; Wan, Lu, and Chen, 2007; Yu et al., 2011). Considering these findings together, the statement by the World Bank that "openness to trade and capital flows that makes markets more global also makes subnational disparities in income larger and persist for longer in today's developing countries" (World Bank, 2008: 12) represents a general agreement among regional scientists and economists of the developing world.

\subsection{The effects of fiscal decentralization}

Theory predicts that fiscal decentralization will increase regional disparity. The central government seems to be an active agent in the restructuring process (as opposed to being a powerless victim) and is relatively successful in maintaining political power over local governments (Allen and Cochrane, 2007; Brenner, 2004; Jessop, 2002; Jones et al., 2005; MacLeod and Jones, 2007; Sonn, 2010). However, the financial resources possessed by the central government have certainly been reduced (Cheshire and Gordon, 1998; MartinezVazquez and McNab, 2003; Prud'homme, 1995; Rodríguez-Pose and Gill, 2004). With fiscal decentralization, less developed regions do not have the economy of scale to provide the same level of public service as developed regions. Such a problem does not exist under the central provision of such services (Rodríguez-Pose and Gill, 2005). Furthermore, developed regions may use extra resources to attract investment that would otherwise have gone to less developed regions. That is, developed regions may have an advantage in addition to the natural tendency of foreign investors to prefer existing agglomerations usually found in these regions (Barrios, Gorg, and Stroble, 2006; Devereux, Griffith, and Simpson, 2007; Sonn and Lee, 2012). These problems are commonplace, but are more serious in developing countries where the conditions for economic growth vary tremendously across regions, and where regional disparity is already high.

These theoretical predictions are supported by empirical studies. In China, Tsui (1991), using a graph analysis, and Kanbur and Zhang (2002), using a generalized entropy coefficient, showed that fiscal decentralization increases regional disparity. Zhang (2007) argued that fiscal decentralization causes stronger regional inequality when it is combined with political centralization. In this case, local bureaucrats have a strong incentive to promote economic growth to enhance their political status. Hao and Wei (2010) tested globalization and decentralization and found that both factors increased the regional disparity between the inland and coastal regions in China. Dillinger and Webb (1999) and Rao and Singh (2007) reported similar findings in Brazil and India, respectively. A cross-country analysis by Rodríguez-Pose and Ezcurra (2009) found that fiscal decentralization is positively correlated with regional disparity in developing countries, but not in developed countries.

Overall, there seems to be a certain degree of agreement, at least within the context of developing economies, that state restructuring, both upward and downward, is likely to increase regional disparity. This study examines this prediction empirically in the context of Indonesia.

This study offers two contributions to existing literature on the topic. Firstly, we focus on Indonesia, a country that has not been explored in detail prior research, as the majority of related research within the developing world is based on analyses of Mexico and China (Dillinger and Webb, 1999; Rao and Singh, 2007; Rivas, 2007; Rodríguez-Pose and Ezcurra, 2009). In spite of its importance in terms of size and the growth rate, regional disparity in Indonesia has attracted far less academic attention. The much debated issues of local 
governments and their service deliveries within the context of decentralization (Gonschorek, Hornbacher-Schönleber, and Well, 2014; Kis-Katos, and Suharnoko Sjahrir; 2014; Sjahrir, Kis-Katos, and Schulze; 2013; 2014; Sujarwoto, 2012) should influence spatial disparity but few explicitly look at such influence. As such, a study on Indonesia is valuable in its own right.

More importantly, the Indonesian experience offers insight into more general theorization of regional disparity and state restructuring beyond that of an individual country, for two reasons. Firstly, unlike in China, Indonesia's fiscal decentralization and trade liberalization happened within a decade and in a more fundamental way, which we explain in the next section. This makes it possible to identify the effect of state restructuring more clearly, as well as letting us examine the interaction between these two changes. Secondly, unlike the North American Free Trade Agreement (NAFTA) which Mexico is part of, the Association of Southeast Asian Nations (ASEAN) Free Trade Area (AFTA) consists mainly of developing countries, and aims for both political and economic integration. As such, Indonesia offers a unique opportunity for us to analyze the impact of simultaneous upward and downward restructuring.

\section{Methodology}

\subsection{The econometric model}

We start with the $\beta$-convergence model proposed by Barro and Sala-i-Martin (1992) and Sala-i-Martin (1996):

$$
\ln \left(Y_{i, t} / Y_{i, t-1}\right)=a+\left(1-\beta_{N}\right) \ln \left(Y_{i, t-1}\right)+u_{i, t},
$$

where $Y_{i, t}$ is the GRDP per capita of region $i$ at time $t$, and $Y_{i, t-1}$ is a measure of the development $t_{1-1} ; \beta_{N}$ is the convergence coefficient; $a$ is a constant; and $u_{i, t}$ is a random shock with mean zero and finite variance $\sigma_{u}^{2}$. Since $0<1-\beta_{N}<1$, the log development converges over time to a steady state of $a / \beta_{N}$ in all regions. We use a fixed effect to eliminate endogeneity problems caused by unobserved characteristics of districts and major economic and policy events $\left(\mathrm{u}_{\mathrm{it}}\right)$. Here, $\mathrm{u}_{\mathrm{it}}$ is estimated using a fixed-effect panel data model. The fixed-effect model captures all unobserved time-invariant district factors, such as geographic areas, institutions, interregional heterogeneity, and cultures. The analysis also includes a time fixed effect to observe variations that may occur over time.

The variance of the log development in time $t$ is then derived from (1) as follows:

$$
\sigma_{t}^{2} \cong\left(1-\beta_{N}\right)^{2} \sigma_{t-1}^{2}+\sigma_{u}^{2}
$$

There is persuasive criticism that $\beta$-convergence does not show the status of regional disparity at a point in time and overlooks the possibility of the convergence being limited to a small subset (Quah, 1993; 1997). However, $\beta$-convergence has gained in popularity because it measures the direction of changes in regional disparity well, and has the mathematical flexibility to be used in various econometric models. The basic empirical model we estimate is 


$$
\ln \left(Y_{i, t} / Y_{i, t 1}\right)={ }_{1} \ln \left(Y_{i, t 1}\right)+e_{1}
$$

where $-\beta_{1}$ is the absolute $\beta$-convergence coefficient.

Then, to test the impact of the state restructuring (i.e., the impact of the AFTA and the degree of fiscal decentralization of each region), we first add these two variables to the model. Thus, our empirical model is as shown in equation 4

$$
\ln \left(Y_{i, t} / Y_{i, t 1}\right)={ }_{2} \ln \left(Y_{i, t 1}\right)+p D E V O L_{i, t}+q \text { AFTA }_{i, t}+e_{2},
$$

where $D E V O L$ is a measure of fiscal decentralization, AFTA denotes the AFTA effects, and $-\beta_{2}$ is the conditional $\beta$-convergence coefficient. These indices are constructed using the principle component factor (PCA) analysis ${ }^{2}$. The methodology is commonly used in economic studies to construct an index that extract the variance of a phenomenon of multiple variables such as Annoni and Dijkstra (2013), Costantini, et al (2016); and Deininger et al (2011).

We also add the usual control variables: 1) the direct and independent effect of human capital; 2) the technological level of each district; 3) the effect of the share of people living in urban areas; 4) the private investment in each district; 5) the public infrastructure; and 6) a dummy variable for border regions, which measures the benefit of geographical proximity to potential trade partners.

The last control variable is the lobbying capacity of local governments to earn the special allocation fund (Dana Alokasi Khusus; DAK) as a proportion of DAK to the total amount of government transfer. There is partial evidence that the fund's allocation is influenced by national parliament and/or local lobbying behavior (Usman et al, 2008). Local leaders need to lobby to obtain funding as there is a certain level of "subjectivity" in the allocation of this fund. This is because the fund is allocated to the line agencies that enumerate the activities on which funds should be spent, but the funds are part of local budgets and are deposited in local government bank accounts.

\subsection{Data sources}

The statistical data were collected from various institutions, including the Central Bureau of Statistics (Badan Pusat Statistik; BPS), the Ministry of Finance (MoF), the Ministry of Trade, and the ASEAN Secretariat. The regional variables were collected from the BPS regional list publication ${ }^{3}$ that includes a complete list of districts. The 1997 regional list consisted of 292 districts, ${ }^{4}$ made up of 232 regencies and 60 municipalities. The number expanded during the decentralization in 2005 to 350 districts. These new districts are included when they exist. We use time-series data for the period 1993-2005. All data are available for these districts in the observation period except for the regional budget data, which are available from 1994. The full list of control variables and data sources is provided in the Appendix.

\footnotetext{
${ }^{2}$ PCA is a statistical methodology to reduce the number of variables of interest into a smaller set of components. All the variance in the variables are included it into a new set of components equal to the number of original variables.

${ }^{3}$ Available at www.bps.go.id.

${ }^{4}$ The Special Region of Capital Jakarta is a province with five non-autonomous districts and one regency.
} 


\subsection{Measuring fiscal decentralization}

The Indonesian fiscal transfer employs two measures of fiscal decentralization, namely the share of owned-source revenue on total revenue and proportion of expenditure over GRDP. The former proximate the effect of fiscal decentralization on local tax and retribution collection efficiency following McCulloch and Sjarir (2008). The latter follows the OECD database measurement on fiscal decentralization ${ }^{5}$.

\subsection{Measuring the impacts of the AFTA}

We measure the impact of the AFTA using the tariff level that impacts a region. The impact will differ in each region because, like most free trade agreements, the AFTA sets different tariff levels for different industrial sectors, and industries are not evenly distributed across regions. If a big part of a region's industrial composition happens to be a sector that has a low tariff level under the AFTA, the AFTA's impact on that region will be greater, and vice versa. As such, we construct a measure that reflects two factors: 1) the level of the tariff in each industrial sector; and 2) the industrial composition of a region. The analysis assumes that the increase in imports due to a lower trade barrier in the AFTA-CEPT will increase trade in the regions in which the manufacturers are located.

We use the BPS make data available for each industry-intermediate inputs in their prices - from the survei industri (SI) questionnaire from 1998 and 2002. The 1998 and 2002 data are available in a five-digit industry format and are used to create a 228 manufacturer input/output table. The mix of inputs by industry is assumed to be fixed over time ${ }^{6}$. The available dataset is an unbalanced panel of around 21,000 firms per year with 274,061 observations.

The input and output tariffs of the AFTA-CEPTs are obtained from the ASEAN Secretariat. The output tariff measures the import value of a product and the input tariff measures the import value of raw materials within a district's industry in each industrial sector.

First, we construct a five-digit output tariff by taking a simple average of the harmonization system (HS) nine-digit codes within each five-digit industry code. This procedure is required to convert the ASEAN HS to an Indonesian standard industrial classification (ISIC) code. We use an unpublished concordance between the HS nine-digit code and the ISIC five digits available from Amiti and Konings (2007). To address concerns about trade structure post-decentralization, we also construct the input/output table for 2002.

Second, for each five-digit industry, we compute an input tariff as a weighted average of the import tariffs (equations 5 and 6). The weights, $w_{j k}^{1998}$, are the cost shares of industry $j$ in producing goods in industry $k$, based on data from 1998 . For example, if industry $k$ uses $60 \%$ paper sacks and $40 \%$ cement, then we calculate the overall weight using a $60 \%$ weight for the paper sacks tariff and a $40 \%$ weight for the cement tariff.

$$
\text { input tariff }_{t}^{k}=w_{j k}^{1998} \times \text { output tariff }{ }_{t}^{j},
$$

\footnotetext{
${ }^{5}$ See http://www.oecd.org/tax/federalism/oecdfiscaldecentralisationdatabase.htm\#C_3

${ }^{6}$ Assuming a Cobb-Douglas technology (Amiti and Konings, 2007).
} 


$$
w_{j k}^{1998}=\frac{{ }_{i}{ }_{i n p u t}{ }_{i j k}^{1998}}{{ }_{i j} i_{i n p u t}^{1998}} .
$$

Third, we perform a similar calculation to obtain the tariff impact on individual districts (equations 7 and 8). Here, we compute an input and output tariff impact as a weighted average of the industry's share within the district:

$$
\begin{gathered}
\text { district tariff } t_{t}^{l}=w_{l}^{1998} \times \text { output(input) } \text { tariff }_{t}^{k}, \\
w_{l}^{1998}=\frac{{ }_{i} \text { input }(\text { output })_{k l}^{1998}}{{ }_{i j} \text { input }(\text { output })_{k l}^{1998} .}
\end{gathered}
$$

\subsection{Construction of fiscal decentralization and AFTA Indices}

We construct the decentralization index with PCA analysis for individual district $\mathrm{i}$ at time $t$, with four variables representing decentralization and $\mathrm{AFTA}^{7}$. The result is as the following table (Table 2):

\section{<<Table 1 Around here >>}

The table shows the result of PCA indicating that the third principal component (P3) increases with increasing trade openness and tariff weight per districts. This component can be viewed as a measure of AFTA effect. The fourth principal component (P4) increases following the increase of government expenditure and share of OSR, which reflects the decentralization. This suggest that higher rates of decentralization are found in districts with higher government expenditure and also tend to have higher share of Total Revenue.

\section{Exploratory analysis}

\subsection{Regional disparity in Indonesia}

Simple measures of regional disparity indicate regional convergence. We use familiar measures such as the Gini Coefficient, Theil Entropy Index, and Coefficient of Variation for the period 1993-2006 (see Fig. 1). The years 1998 and 2001 are used as references to explain the inequality dynamics during the sub-periods. During 1994-1997, inequality trend has increased rapidly until 1998, and became relatively stagnant until 2001. Interestingly, this

\footnotetext{
${ }^{7}$ We conduct the PCA analysis using the "pca" command in STATA 14. The PCA scores for P3 and P4 are stored using the command "predict" and are used as indices in the regressions
} 
inter-district inequality trend declined throughout the post-decentralization period. ${ }^{8}$ The map in Fig. 2 depicts the average annual economic growth of the districts between 1993 and 2005. The darker shades represent higher annual district economic growth. The figure suggest that higher economic growth occurs in districts located in rich provinces, such as the financial and manufacturing industry centers (e.g., Jakarta, West and East Java), and provinces endowed with natural resources (e.g., Riau and East Kalimantan).

\section{Figure 1 Between-district inequality per capita GDP, 1993-2006}

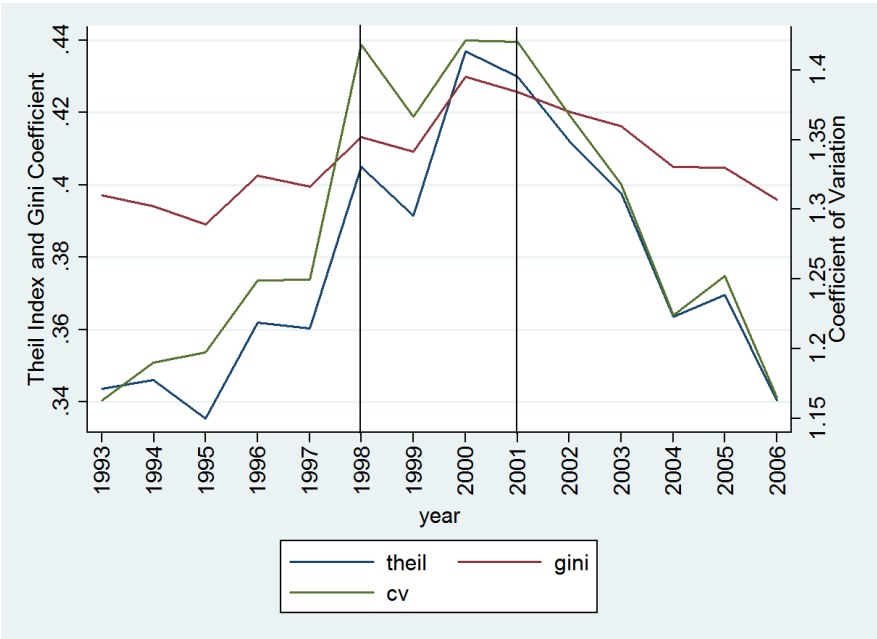

Source: Author's own calculation

Figure 2 District Economic Growth (GRDP pc 1993-2005)

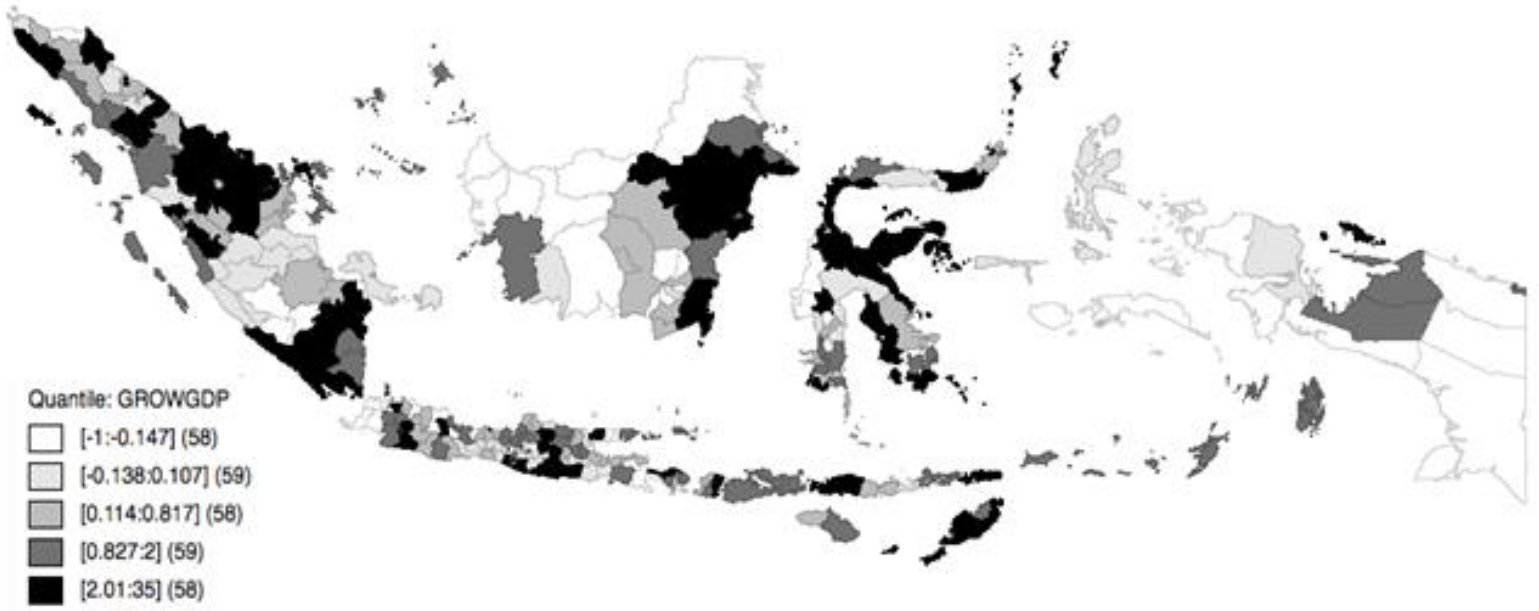

Source: Authors' analysis

${ }^{8}$ If we decompose to three types of regional division-within province, between province, and between regions - we observe that the disparity among districts within provinces has declined sharply, whereas the disparity between provinces has also declined, although not significantly. An interesting finding is that the disparity between regions (Indonesia's regions are commonly separated into the western, middle, and eastern parts of the country) increased from the early 1990s and peaked during the early 2000s before reaching its current position. This supports that the eastern region of Indonesia has been left behind severely in terms of its economic welfare. For a full discussion on the various aspects of disparity in Indonesia, please see Aritenang (2012). 


\subsection{Fiscal decentralization}

Within three years of the fiscal decentralization of 1999, regional autonomy grew rapidly (Brodjonegoro, 2003). The original 1999 law on decentralization was revised in 2004. In the former law, provinces and municipalities endowed with natural resources gained more revenue than other regions (70-80\%), and this share increased by $0.5 \%$ in the revised law. However, this shift has not guaranteed economic development in these regions. Moreover, this change does not mean a complete shift of importance between local governments and the central government. Five years after decentralization, local government expenditure on development remains below half of the central government's expenditure. Furthermore, the local development budget has declined rapidly compared to that of the central government. Central government transfers remain as the main source of the development budget.

The central government remains in control of important tax sources, including income tax, land and property tax, and natural-resource taxes. Provinces are responsible for vehiclerelated taxes and districts are allowed to tax entertainment and hospitality taxes. Overall, the field survey found complaints by the heads of regions on the share of taxes between the central and the local governments.

To observe the impact of decentralization, the index is constructed as a combination of district fiscal dependency and financial capacity. The difference between the decentralization indices for the initial and end periods are presented in Fig. 3. The map shows that decentralization has resulted in higher economic growth in districts in Java Island. Interestingly, higher economic growth is also found in districts in the bordering regions, for example, in Sumatra, Bali, and West Nusa Tenggara.

Figure 3 Changes in Decentralization 1993-2005

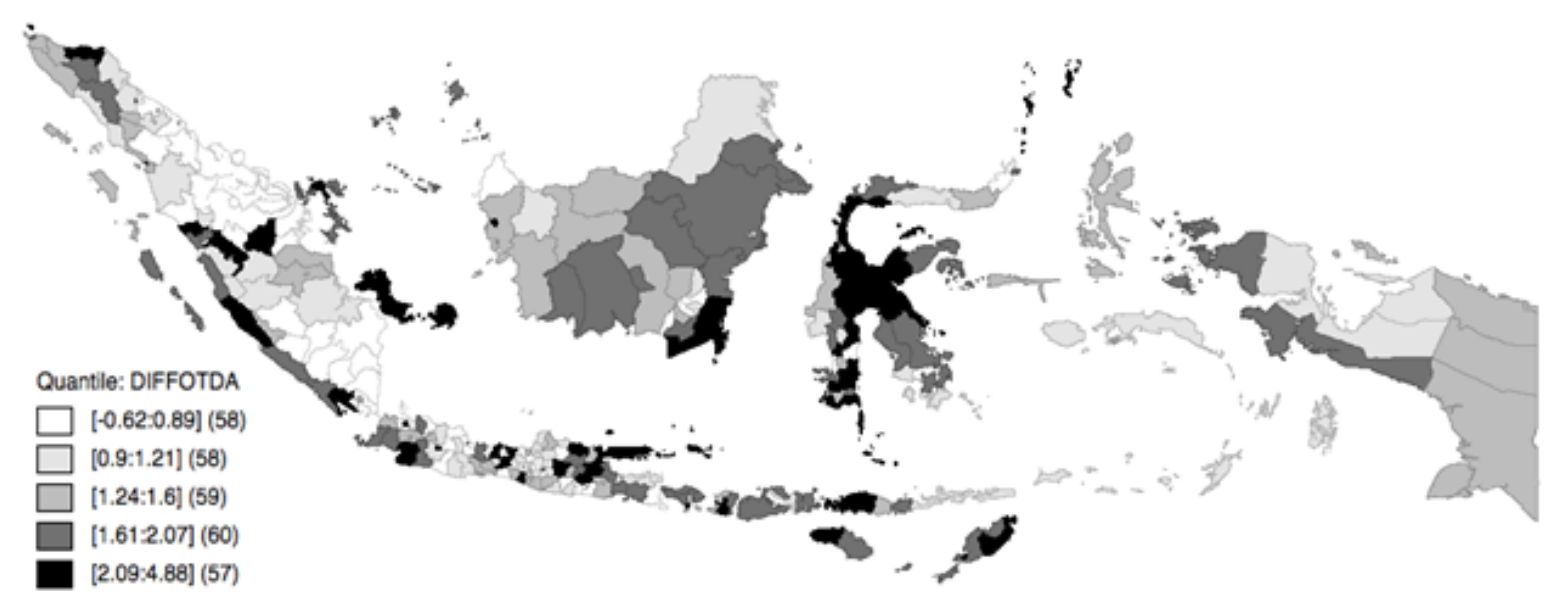

Source: Authors' analysis

\subsection{Changes in trade openness}

This section discusses the impact of the AFTA tariff on regional economic growth. Table 1 shows the impact of the AFTA on regions, based on the number of industries, in 1993 and 2005. Each row shows how the number of industries benefiting from the AFTA decreases at the $0-5 \%$ level and increases significantly at the level greater than $5 \%$. More specifically, the sub-sectors that benefit the most are DISIC 31and 39, which are the food 
industries and other industries (including light equipment), respectively. The classification list on tariff lines and industry outputs are different. The tariff lines follow the harmonized commodity description and coding system (HS) at the nine-digit level, while the outputs of the manufacturing industries are coded using the ISIC.

Using the unpublished references from the BPS, Amiti and Konings (2007) calculated a final good tariff for each five-digit industry in 1991, 1995, and 2001. The same tariff for 2005 was constructed by Widodo (2008). The table indicates that the CEPT tariffs are much lower than the MFN tariffs, and even metals products (ISIC 36) has no tariff barrier to enter Indonesia in 2005. Table 1 also shows the changes in the average tariff rate and its growth for each sector in the manufacturing industry during the period. The table shows that Indonesian industry was liberalized after the early 1990s and peaked during the second half of the decade. The tariff on paper products (ISIC 34) appears to be the tariff with the greatest reduction, with an average of more than $35 \%$ between each period (see Table 1).

\section{$<<$ Table 2 Around here $>>$}

Based on the industrial composition of each district, we calculate the AFTA effects for each district (see Fig. 4). During the period 1993-2005, the AFTA tariff rate applied the most to the bordering districts of Sumatra, Kalimantan, and Sulawesi. In Java, the districts that experienced high levels of tariff growth were located in industrial provinces such as Jakarta, West Java, and East Java.

Figure 4 Changes in the AFTA Effect by District, 1993-2005

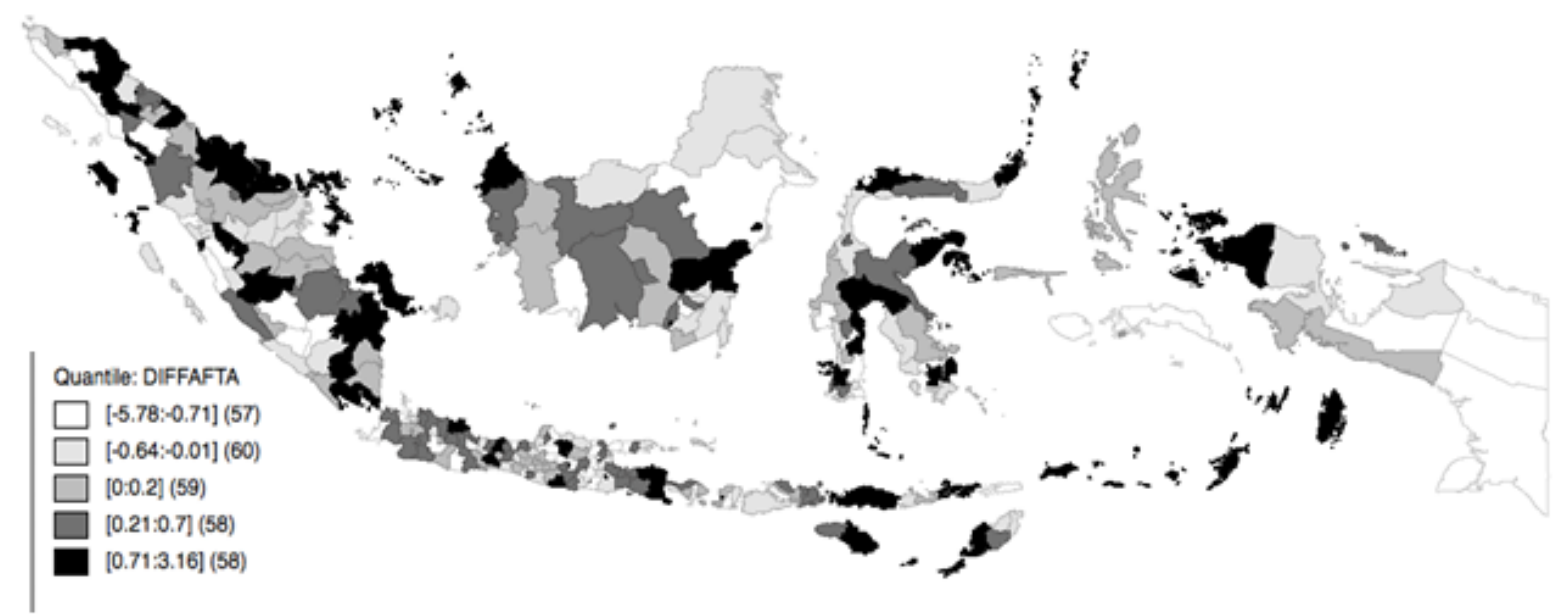

Source: Authors' analysis

\section{Econometric analysis}

Building upon our exploratory analyses, we estimate an econometric model to show that state restructuring actually furthers regional disparity in Indonesia, as in other countries. As described earlier, our data are panel data, so we first need to decide between a fixed effect analysis and a random effect analysis. A Hausman test result suggests the former is appropriate. 
There are missing data in almost all control variables, which leads to a reduction in the number of observations and the panel data analysis. For example, while there are 4,088 observations in the full dataset, there are only 924 observations for 296 districts for the period 1993-2005. We do not conduct any manipulation, backcast or forecast for the missing data as it may cause bias regression result and interpretation. On the other hand, the OLS analysis $\mathrm{R}^{2}$ are between 0.26-0.3, which are in the same range with previous research such as $0.2-0.36$ (Resosudarmo and Vidyattama, 2006)

\subsection{Impacts of decentralization and the AFTA on regional growth}

In the econometric analyses, we can think of the models as step-wise estimations and compare the changes in coefficients between the models to explain the effects of decentralization and the AFTA on the $\beta$-convergence. We compare Models 1 and 4 as one set and Models 5 and 8 as another. The first set has $\beta$-convergence and two key variables (decentralization and AFTA), while the second includes all control variables in addition to the previous three. In each of the sets, the two key variables were added step-wise to the baseline models of each set, namely Models 1 and 5. Then, we observe how the addition or the omission of the key variables changes the $\beta$-convergence coefficient.

First, we find consistent convergence across the models. The sign of the $\beta$-convergence coefficient is negative across the models, which confirms there is neoclassical convergence across districts in Indonesia.

Second, decentralization and AFTA has different sign on economic growth. First, decentralization has a positive sign suggesting that larger fiscal decentralization leads to higher economic growth. In our paper, as fiscal decentralization is proximated by share of revenue and expenditure, the finding suggests that higher share of revenue and expenditure in decentralization period boost local economic growth. Second, the AFTA negative sign suggest that lower tariff barrier accelerates trade and economic growth.

Comparing models with the decentralization variable against the models without, we find that by controlling the decentralization variable increase the convergence rate. We can compare Model 3 against 4 and Model 5 against 6. In both cases, convergence is stronger in the models with decentralization variable, which means, the effects of decentralization might be obstructing the convergence potential of Indonesian regional economy. On the other hand, interaction variable between AFTA and convergence variable suggest that trade liberalization is insignificant on determining regional convergence in the decentralization era.

Next, we found the significant negative impact of the AFTA on regional economic growth, suggesting that the elimination of tariffs and a higher level of trade penetration are associated with contracts economic growth. The institutional economics could explain this finding as the effects of trade openness are determined by several factors such as the preferential trade agreement, the agreement's capacity to produce trade creation and trade diversion, and the economic power of nation-states or regions. Another possible explanation is the variation of regional characteristics, where regions with abundant natural resources and infrastructure accessibility are abler to attract investment and economic activities. This, in the long run, leads to divergence among districts. Thus, despite AFTA is significant to promotes regional convergence, the convergence rate of decentralization is higher, ceteris paribus.

In addition, note that the significant contribution of the AFTA tariff elimination is at its maximum level, as the AFTA-CEPT tariff is presently the same as the MFN tariff. Thus, to optimize the impact of the AFTA tariff, districts should accelerate their international trade penetration. Another explanation is the country's revealed comparative advantage (RCA), 
which has a higher ratio of total exports than the share of total world exports in certain commodities, particularly in the case of agro-based, wood-based, and fisheries-based commodities (Octaviani et al., 2007). Similarly, the vertical intra-industry trade (IIT) measure suggests that Indonesia's economy is mostly linked with regional trade via the automotive and rubber-based sectors.

At the supranational level, the ASEAN way governance embedded in the AFTA allows individual countries to set their own trade modalities. The ASEAN way emphasizes dialog, consultation, consensus-building, and non-binding commitments (Yuzawa, 2012), and has made this loose free-trade agreement possible. Hence, member countries only open their trade barriers once the sector and products are considered to be ready for free trade. Finally, the MFN regulation requires that a member country that has an FTA agreement with a country outside the ASEAN should provide a similar advantage to ASEAN members. This policy has benefited Indonesia through trade and market expansion.

\section{$<<$ Table 3 Around here $>>$}

\subsection{Impacts of decentralization and AFTA on regional convergence: A period comparison}

This section compares the impact of decentralization and AFTA between three periods: predecentralization, decentralization, and for the overall period. A further explanation is given according to the figures in the tables (columns 5-8 in Table 2 and Table 3). Across the models, the $\beta$-convergence confirms that the poorer regions grew faster in 1993 and 2005. Specifically, there is a rising trade index reduces regional economic growth in the early decentralization.

The AFTA significantly contribute significantly to economic growth only in the predecentralization, suggesting the importance of trade liberalization in the period. However, in the whole period, the AFTA impact faded. A possible explanation for this is that as trade liberalization progressed, the tariff elimination stagnated, along with the AFTA impact. Furthermore, as explain above, AFTA impact became negative in decentralization period indicating trade liberalization accelerate economic growth only in selected advance districts

However, this economic force was offset by the decentralization effect as fiscal autonomy enhanced regional divergence after 2001. This finding is confirmed by the consistent positive sign of decentralization index in both decentralization and whole period. On the other hand, location and technology advancement variables were not significant in the pre-decentralization period. However, in the decentralization period, these variables were consistently significant for economic growth. This finding confirms the importance of infrastructure and technology spillover on economic growth.

Furthermore, education attainment and population growth are not associated with economic growth. Interestingly, districts that have higher share of DAK, suggesting its higher lobbying capacities, tend to have economic growth, suggesting these districts are lagging districts.

$<<$ Table 4 Around here $>>$ 


\section{Conclusion}

The study of disparity was conducted in various Indonesian regions. Using unconditional convergence models, we observed the process of convergence, consistent with the findings of Resosudarmo and Vidyattama (2006) and Akita and Alisjahbana (2002).

From the econometric analyses of the $\beta$-convergence, we can draw several conclusions. First, all regressions conducted in this study show a significant convergence rate, indicating that poorer districts grow faster than more advanced districts do. Second, decentralization has a positive impact on economic growth, and this effect is stronger for developed regions, thereby reducing the speed of convergence. This paper uses an innovative proxy to estimate the impact of AFTA by looking at the effect of AFTA tariff weighted to individual districts, found that the effect of the AFTA was inconsistent across models, in fact, this variable reduced the convergence rate, which calls for further research on this matter. Our analysis suggests their findings are not robust and may change when analyzed using a different method. Feridhanusetyawan and Pangestu (2003), using the computable general equilibrium model, found only a small positive effect of the AFTA.

Interestingly, the study also confirms the importance of infrastructure and technology advancement on economic growth, but it similar result was not found for human capital and population growth. This could interpret by two things; first, human capital in Indonesia is at the similar level thus it does not cause variation of local economic growth, or second, the data fails to proximate the effect of human capital on economic growth.

The findings of our study provide two potential research extensions. First, an analysis of a longer period will provide a more comprehensive study of the effects of the AFTA and decentralization, especially during the current world economic crisis. Furthermore, as the limited scoop of trade integration, the study of economic integration effect on sub-national districts should consider other aspects of integration such as institutions and socio-politics, in which are part of the three pillars of ASEAN Economic Community (AEC).

Second, including institutional and governance aspects in the analysis will improve this study. Local institutions and capacities will be crucial in shaping local policies that develop local endowments and infrastructure. 


\section{APPENDIX}

Table of Variables

\begin{tabular}{|c|c|c|c|}
\hline No & Variable & Definition & $\begin{array}{c}\text { Data } \\
\text { Source }\end{array}$ \\
\hline 1. & $\begin{array}{c}\text { Gross Regional Domestic } \\
\text { Product }\end{array}$ & Real GRDP per capita & BPS \\
\hline 2. & Decentralisation Index & $\begin{array}{c}\text { Index of share of local revenues and share of } \\
\text { intergovernmental transfers of total revenue, per } \\
\text { district }\end{array}$ & MoF \\
\hline 3. & AFTA Index & $\begin{array}{c}\text { Index of weighted Indonesian CEPT Tariff and total } \\
\text { value of Indonesia manufacturing exports and } \\
\text { imports, per district }\end{array}$ & $\begin{array}{c}\text { ASEAN Secretariat } \\
\text { and BPS }\end{array}$ \\
\hline 4. & $\begin{array}{c}\text { Share of people ever/being in } \\
\text { junior high school and } \\
\text { vocational }\end{array}$ & $\begin{array}{c}\text { Percentage of people has a junior high school } \\
\text { education per district }\end{array}$ & BPS \\
\hline 5. & Population Growth & Percentage of annual Population Growth & $\begin{array}{c}\text { BPS/Indo- } \\
\text { Dapoer }\end{array}$ \\
\hline 6. & $\begin{array}{c}\text { Share of road that are accessible } \\
\text { for vehicles }\end{array}$ & $\begin{array}{c}\text { Percentage of roads that are accessible for vehicles } \\
\text { per district }\end{array}$ & \begin{tabular}{c} 
BPS \\
\hline 7
\end{tabular} \\
\hline 8. & Technology & $\begin{array}{c}\text { Proximity for industry technological level using the } \\
\text { total factor productivity (TFP) }\end{array}$ & BPS \\
\hline & Lobby Capacities & Share of DAK to total central government transfer. & $\begin{array}{c}\text { BPS/Indo- } \\
\text { Dapoer }\end{array}$ \\
\hline
\end{tabular}




\section{References}

Allen J., Cochrane A. (2007): "Beyond the territorial fix: regional assemblages, politics, and power," Regional Studies 41, 1161-75.

Annoni P. and Dijkstra L. 2013. EU Regional Competitiveness Index RCI. Report EUR 26060

Aritenang, A.F. (2012): The Impact of State Restructuring on Indonesia's Regional Economic Convergence, Unpublished PhD Thesis, Bartlett School of Planning, University College London, UK.

Ades, A.F., \& Glaeser, E.L. (1995): Trade and circuses: Explaining urban giants, Quarterly Journal of Economics 110(1), 195-227.

Amiti, M. \& Konings, J. (2007): Trade Liberalisation, Intermediate Inputs and Productivity: Evidence from Indonesia , American Economic Review, 97(5): 1611- 1638.

Barro, R. J. and Sala-i-Martin, X. X. 1992. Convergence. Journal of Political Economy, 100 (2): 223-251

Barrios, S., Bertinelli, L., \& Strobl, E. (2006): Coagglomeration and spillovers, Regional Science and Urban Economics 36(4), 467-481.

Brenner N. (2004): New State Spaces: Urban Governance and the Rescaling of Statehood (Oxford University Press, Oxford).

Bru"lhart, M., \& Sbergami, F. (2008): Agglomeration and growth: Empirical evidence, Journal of Urban Economics, 65(1): 48-63.

Cheshire, P.C., Gordon, I.R. (1998): Territorial competition: some lessons for policy, Annuals of Regional Science, 32: 321-346.

Chiquiar, D. (2005): Why Mexico's regional income convergence broke down, Journal of Development Economics 77(1), 257-275.

Costantini, V, Sforna, G. and Zoli, M. 2016. Interpreting bargaining strategies of developing countries in climate negotiations. A quantitative approach, Ecological Economics, 121:128-139.

Deininger, K. and Byerlee, D. 2011. Rising global interest in farmland: can it yield sustainable and equitable benefits? Agriculture and Rural Development. The World Bank

Daumal, Marie and Selin Özyurt (2011): The Impact of International Trade Flows on the Growth of Brazilian States, DIAL Working Papers, Développement, Institutions \& Analyses de Long terme: Paris.

Devereux, M., Griffith, R., \& Simpson, H. (2007): Firm Location Decisions, Regional Grants and Agglomeration Externalities, Journal of Public Economics 91(3-4), 413-435.

Dillinger, W., Webb, S. B. (1999): Fiscal Management in Federal Democracies: Argentina and Brazil. World Bank Policy Research Working Paper 2121.

Egger, P., Huber, P., \& Pfaffermayr, M. (2005): A note on export openness and regional wage disparity in Central and Eastern Europe, Annals of Regional Science 39(1), 63-71.

Faber, B. (2007): Towards the spatial patterns of sectoral adjustments to trade liberalisation: The case of NAFTA in Mexico. Growth and Change 38(4), 567-594.

Hanson, G.H. (1997): Increasing returns, trade, and the regional structure of wages, Economic Journal 107(440): 113-133.

Hanson, G.H. (1998): Regional adjustment to trade liberalisation, Regional Science and Urban Economics 28(4): 419-444.

Hao, Rui, and Zheng Wei (2010): Fundamental causes of inland-coastal income inequality in post-reform China, Annals of Regional Science 45: 181-206

Jessop B. (2002): The Future of the Capitalist State (Polity Press, Cambridge). 
Jones M., Goodwin M., Jones R., 2005, "State modernization, devolution, and economic governance: An introduction and guide to debate," Regional Studies 39, 397-403.

Kanbur, R. and Zhang, X. (1999): Which Regional Inequality? The Evolution of Rural Urban and Coastal Inequality in China from 1983 to 1995, Journal of Comparative Economics 27, 686-701.

Krugman, P. (1980): 'Scale economies, product differentiation, and the pattern of trade'. American Economic Review 70, pp. 950-59.

Lee Seok-Hee and Kang Myoung-Gu. (2012): A study on simultaneous centralized and decentralized urban growth. International Journal of Urban Sciences. Vol.17(1). pp. 5670

Lewis, B.D. (2001): The New Indonesian Equalisation Transfer. Bulletin of Indonesian Economic Studies, 37, pp.325-343.

Macleod G., Jones M. (2007): "Territorial, scalar, networked, connected: in what sense a 'regional world'?,' Regional Studies 41, 1177-1191.

Martı'nez-Va'zquez, J., McNab, R. (2003): Fiscal decentralization and economic growth, World Development 31, 1597-1616.

McFarquhar, A. (1996): "Regional policyeconomics or politics?: experience in Europe," Discussion Paper 64, Cambridge: Department of Land Economy, University of Cambridge.

Nitsch, V. (2006): Trade openness and urban concentration: New evidence, Journal of Economic Integration 21(2), 340-362.

Pepinsky, T.B. and Wihardja,M.M. (2011): Decentralization and Economic Performance in Indonesia. Journal of East Asian Studies 11 (3), 337-371.

Pernia, E.M., \& Quising, P.F. (2003): Trade openness and regional development in a developing country, Annals of Regional Science 37(3), 391-406.

Prud'homme, R. (1995): On the Dangers of Decentralization, World Bank Policy Research Working Paper, 1252.

Quah, D. T. (1993): Galtonís Fallacy and the Convergence Hypothesis. Scandinavian Journal of Economics 95, 427-443.

Quah, D. T. 1997. Empirics for Growth and Distribution: Stratification, Polarization, and Convergence Clubs. Journal of Economic Growth 2, 27-59.

Ramcharan, R. (2009): Why an economic core: Domestic transport costs, Journal of Economic Geography 9(4), 559-581.

Rao, M. G., Singh, N. (2007): The Political Economy of India's federal system and its reform, Publius The Journal of Federalism 37, 26-44.

Renaud, B., 1981, National Urbanization Policy in Developing Countries, Washington D.C.: The World Bank.

Rivas, M. G., (2007): The Effect of trade openness on regional inequality in Mexico, The Annals of Regional Science 41: 545-561

Rodríguez-Pose, A. \& Ezcurra, R., (2010): Does decentralization matter for regional disparities? A cross-country analysis, Journal of Economic Geography 10 (5), pp. 619644.

Rodríguez-Pose, A. \& Ezcurra, R., (2011):, Is fiscal decentralization harmful for economic growth? Evidence from OECD countries, Journal of Economic Geography 11 (4), pp. 619-643.

Rodriguez-Pose, A., Gill, N. (2004): Is there a global link between regional disparities and devolution?, Environment and Planning A 36, 2097-2117. 
Rodriguez-Pose, A., \& Sanchez-Reaza, J. (2005): Economic polarization through trade: Trade liberalization and regional growth in Mexico, In A. J. Venables \& R. Kanbur (Eds.), Spatial inequality and development, Oxford, UK: Oxford University Press.

Rodriguez-Pose, A. \& Gill, N., (2005): On the 'economic dividend' of devolution. Regional Studies, 39(4), pp.405-420.

Rodríguez-Pose, A. \& Gill, N.,(2006): "How does trade affect regional disparities?," World Development, Elsevier, vol. 34(7), pages 1201-1222.

Rodríguez-Pose, A., Tijmstra, S.A.R., \& Bwire, A., (2009): "Fiscal decentralisation, efficiency, and growth" Environment and Planning A 41(9) 2041- 2062

Saad, I., (2001): Indonesia's Decentralization Policy: The Budget Allocation and Its Implications for the Business Environment, SMERU Institute.

Sala-i-Martin, X. X. (1996): Regional Cohesion: Evidence and Theories of Regional Growth and Convergence. European Economic Review 40, 1325-1352.

Sjöberg, Ö. \& Sjöholm, F., (2004): Trade Liberalisation and the Geography of Production: Agglomeration, Concentration, and Dispersal in Indonesia's Manufacturing Industry. Economic Geography, 80(3), pp.287-310.

Sonn J.W., (2010): "Contesting state rescaling: an analysis of the South Korean state's discursive strategy against devolution," Antipode 42(5), 1200-1224.

Sonn, Jung Won and Dongheon Lee (2012): "Revisiting the branch plant syndrome: Review of literature on foreign direct investment and regional development in Western advanced economies", International Journal of Urban Sciences, 16(3) pp. 243-259

Tsui, K. (1991): China's Regional Inequality: 1952-1985, Journal of Comparative Economics 15, 1-21.

Usman, S., Mawardi, M.S., Poesoro, A., Surhayadi, A., and Sampford, C. (2008): Mekanisme dan Penggunaan Dana Alokasi Khusus (DAK), SMERU Research Institute.

Wan, Guanghua, Ming Lu and Zhao Chen, (2007): Globalization and Regional Income Inequality: Empirical Evidence from Within China, Review of Income and Wealth 53(1), $35-59$

Yu, Kang, Xian Xin, Ping Guo, and Xiaoyun Liu (2011): Foreign direct investment and China's regional income inequality, Economic Modelling 28 (2011), 1348-1353.

Yuzawa, Y., (2012): The Fallacy of Socialisation?: Rethinking the ASEAN Way of institution-building, in Ralf Emmers (Ed), ASEAN and the Institutionalisation of East Asia, pp. 75-88

Zhang, J. (2007): China's economic growth: trajectories and evolving institutions, WIDER Conference Paper, United Nations University, Finland.

Gonschorek, Gerrit-Johannes, Sophia Hornbacher-Schönleber, and Mareike Well. (2014) Perceptions of Indonesia's Decentralization-The Role of Performance Based Grants and Participatory Planning in Public Health Service Delivery. Southeast Asian Studies at the University of Freiburg Occasional Paper Series. Freiburg: Federal Ministry of Education and Research

Kis-Katos, Krisztina and Suharnoko Sjahrir, Bambang, (2014) The Impact of Fiscal and Political Decentralization on Local Public Investments in Indonesia. IZA Discussion Paper No. 7884. Available at SSRN: http://ssrn.com/abstract=2381136

Sjahrir, Bambang Suharnoko, Krisztina Kis-Katos, and Günther G. Schulze. (2013). Political budget cycles in Indonesia at the district level. Economics Letters, 120(2), 342-345.

Sjahrir, Bambang Suharnoko, Krisztina Kis-Katos, and Günther G. Schulze. (2014) "Administrative overspending in Indonesian districts: The role of local politics." World Development 59: 166-183. 
Sujarwoto, Sujarwoto. (2012) "Political decentralization and local public services performance in Indonesia." Journal of Public Administration and Governance 2, no. 3: $55-84$. 